\title{
Progress in the Gondwanan Carboniferous-Permian palynology and correlation of the Nilawahan Group of the Salt Range, Pakistan: A brief review
}

\author{
IRFAN U JAN \\ National Centre of Excellence in Geology, University of Peshawar, Peshawar, Pakistan. \\ e-mail: irfan_nceg@yahoo.com
}

This paper comprises of two sections. The first section describes challenges in the Carboniferous-Permian Gondwanan stratigraphic palynology, and progress in techniques such as presence of the "rare-marine intervals', and 'radiometric dating' in some Gondwanan successions, e.g., South Africa, Australia and South America, as tools to confidently calibrate these palynozones. The second section describes developments in the palynological work on the Carboniferous-Permian Nilawahan Group of the Salt Range, Pakistan, and summarises their correlation with the coeval succession of the Gondwana continents and with the Russian/International stages.

\section{Introduction}

The Salt Range occupies a crucial position in the geological history of Pakistan both in time and space. In the time, because the late Palaeozoic stratigraphy of the area represents the end of the greatest glaciation of the Phanerozoic earth system, the Carboniferous-Permian, and in space, because during that time it lay next to the landmass now represented by Oman, Saudi Arabia and Yemen (Jan 2012; Stephenson et al. 2013). Hundreds of metres thick Carboniferous-Permian Nilawahan Group sedimentary successions of Pakistan are preserved in the Salt Range and Trans-Indus ranges (i.e., Khisor, Marwat and Surghar ranges; Kummel and Teichert 1970, figure 1), which offer great opportunity for studying the late Palaeozoics, i.e., CarboniferousPermian succession. The Arabian successions have been well-studied, because they contain significant hydrocarbon-reserves and also bear remarkable traces of the advance and retreat of the ice from around the South Polar regions. However, the Salt Range succession have received limited attention, although in this tectonic jigsaw puzzle, it represents a place near the very margin of the vast glaciated region (Jan et al., in review).

Previously, some palynological taxonomic work was undertaken on the Salt Range units and attempts were made to understand their stratigraphic position in relation to the Gondwana continents (e.g., Balme 1970), however, the then palynozones needed robustness in the calibration. Recently, some palynological work has been undertaken on these successions and attempts have been made to correlate them with stratigraphically bestresolved and palaeogeographically nearby located sections of the Gondwana (i.e., Australia and Arabia; Jan et al. 2009; Jan and Stephenson 2011; Stephenson et al. 2013).

Keywords. Carboniferous-Permian; palynology; Tobra Formation; Sardhai Formation; Pakistan. 


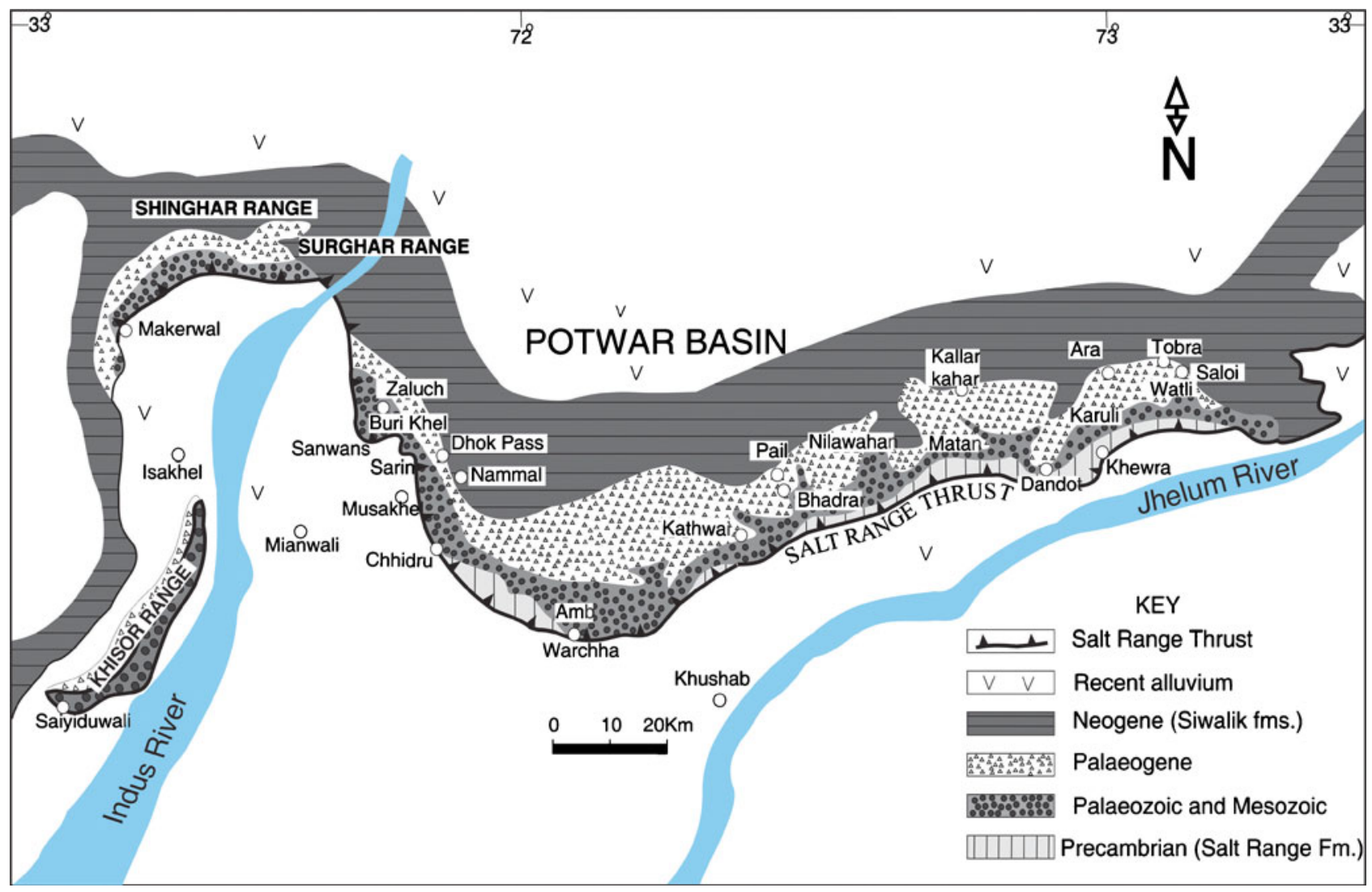

Figure 1. Location map of the Salt Range, Pakistan (modified after Gee 1989; Ghazi and Mountney 2009; Jan and Stephenson 2011).

The main aim of this paper is thus to summarise the progress that has been accomplished in the Gondwanan stratigraphic palynology and also provide information about the work conducted on the palynological correlation of the lowest of the Carboniferous-Permian succession of the Salt Range, i.e., the Nilawahan Group of Pakistan in the context of the presence of rare-marine intervals and radiometrically dated tuffs in other Gondwanan continents that gave confidence to this correlation.

\section{Progress in the Gondwanan Carboniferous-Permian palynology and challenges}

The palynological work on the CarboniferousPermian strata of presently scattered Gondwanan continents (figure 2) is mostly related to coal (in India, Australia and South America) and oil exploration (in Arabia and South America). Most of the palynological work was thus either localized or remained the oil-companies' asset (Stephenson 2008). The progress in the palynology has only been recently made, i.e., in the last few years.
The initiation for this quest for the research in Carboniferous-Permian palynology also originated from the existence and importance of the southern hemisphere late Palaeozoic ice age. Widespread late Palaeozoic glacial and deglacial deposits occur in the presently scattered continental fragments of Gondwana, e.g., South America, Africa, Falkland Islands, Antarctica, India, Pakistan (Frakes et al. 1975) and Australia (Visser 1997). These deposits and events of glaciation and deglaciation in them have been correlated using various available information, among them are: pollen and spores (e.g., Kyle and Schopf 1982; Foster and Waterhouse 1988; Lindström 1995), invertebrate fauna (e.g., Amos and López-Gamundi 1981; Archbold 1999), marine flooding surfaces (e.g., López-Gamundi 1989; Isbell et al. 1997), and radiometric dating of the zircon contained in the volcanic tuffs (e.g., Roberts et al. 1996; Bangert et al. 1999). Among these methods the correlation using palynology is strongly encouraged, because with only few exceptions (e.g., Australia), most of the Late Carboniferous and Early Permian cold climate nonmarine glacial deposits of Gondwana lack marine microfauna, e.g., foraminifera, corals and conodonts (Archbold and Dickins 1997), which form the basis 


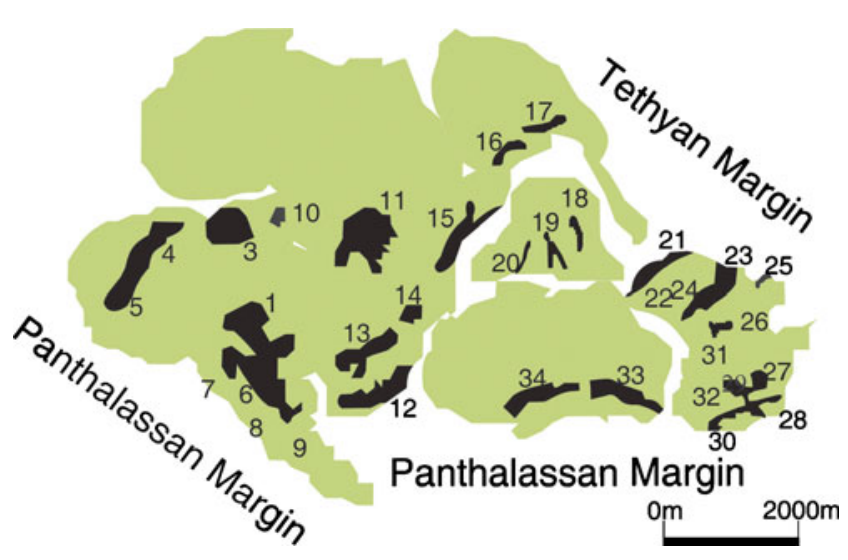

Figure 2. Chief Carboniferous-Permian basins of Gondwana. (1) Paraná, (2) Chacoparaná, (3) Parnaíba, (4) Amazonas, (5) Solimões, (6) Paganzo, (7) CalingastaUspallata, (8) San Rafael, (9) Tepuel, (10) Gabon, (11) Congo, (12) Karoo, (13) Kalahari, (14) Zambezi, (15) Tanzanian-Malagasy, (16) Yemen, (17) Oman, (18) Himalayan zone, (19) Satpura, Son-Mahanadi, KoelDamodar, (20) Godavari, (21) Carnarvon, (22) Collie-Perth, (23) Canning, (24) Officer, (25) Bonaparte, (26) Pedirka, (27) Galilee, (28) Bowen-Gunnedah, (29) Cooper, (30) Sydney, (31) Arckaringa, (32) Murray, (33) Victoria Land, (34) central Transantarctic Mountains (after Stephenson 2008).

for the standard International stages (Jin et al. 1997). Thus, palynology is developed as a strong tool for inter-basinal correlation and the correlation with the Russian/International stages in these successions (Stephenson 2008).

The few challenges in correlating Gondwana palynological assemblages precisely to the Russian/International stages need appreciation and are attributed to two major reasons.

- The rarely available marine intervals in the Gondwanan deposits having marine fauna, which could help to devise a firm and reliable regional Gondwana-wide framework; (Stephenson 2008).

- The endemism in the palynological assemblages of the Russian/International stages, which were palaeoequatorial during that time and thus demonstrated different taxa (Stephenson 2008).

The presence of the rare marine intervals containing the age-diagnostic non-endemic fauna in certain stratigraphic successions in Australia (Foster and Waterhouse 1988) and the use of the radiometric dating technique in these succession in South America and Africa (Bangert et al. 1999; Césari 2007) have overcome these challenges over the last few years to a great extent and have helped to increase the confidence level of the palynological correlation of the CarboniferousPermian succession. The palynozones in this Gondwanan succession are now more confidently correlated within themselves and significantly with the Russian/International stages.

\section{Stratigraphy, geology and palynological assemblages of the Nilawahan Group, Pakistan}

\subsection{Stratigraphy and geology of the Nilawahan Group}

The Carboniferous-Permian succession of the Salt Range, Pakistan is divided into two groups. The lowermost, i.e., the continental Gondwana succession, represented by the Nilawahan Group (figure 3), and the overlying shallow marine Tethyan succession, represented by the Zaluch Group (Wardlaw and Pogue 1995).

The base of the Nilawahan Group is represented by the Tobra Formation, showing glaciallyinfluenced sedimentation (Ghazi et al. 2012; Jan et al., in review). It is overlain by the Dandot Formation in the Salt Range. The Dandot Formation is absent in the Khisor Range and western Salt Range (figure 3). The Dandot Formation consists of pale grey to olive green sandstone with subordinate dark grey and greenish splintery shales (Shah 1977). It contains the bivalve Eurydesma and the conularid, Conularia. Many species of Bryozoa and Ostracoda along with a few brachiopod taxa have also been described from this formation (Reed 1936; Pascoe 1959). Arid palaeoclimatic conditions are indicated by the succeeding Warchha Formation, which consists of medium- to coarse-grained, purple, arkosic sandstone, conglomeratic in places with interbeds of reddish shale. The conglomerate clasts are mostly granitic, however subordinate quartzitic clasts are also present (Ghazi and Mountney 2009). Humid conditions are indicated by the overlying Sardhai Formation, which consist of bluish to greenish-gray claystone with subordinate sandstone and siltstone interbeds and minor carbonaceous clays (Sultan 2004; Jan 2011).

\subsection{Palynology of the Nilawahan Group}

The palynomorphs in the Nilawahan Group (table 1) are concentrated in two stratigraphic intervals, i.e., the Upper Pennsylvanian to Asselian Tobra Formation (Jan and Stephenson 2011; Stephenson et al. 2013, figure 4) and the Middle Permian (Wordian) Sardhai Formation (Jan et al. 2009, figure 4). The Dandot and overlying Warchha formations have not yielded palynomorphs.

Jan and Stephenson (2011) studied the Tobra Formation palynological assemblage at the Zaluch Nala section (western Salt Range; figure 3) and Stephenson et al. (2013) studied Tobra Formation palynological assemblages at the KhewraChoa section (eastern Salt Range; figure 3). These 


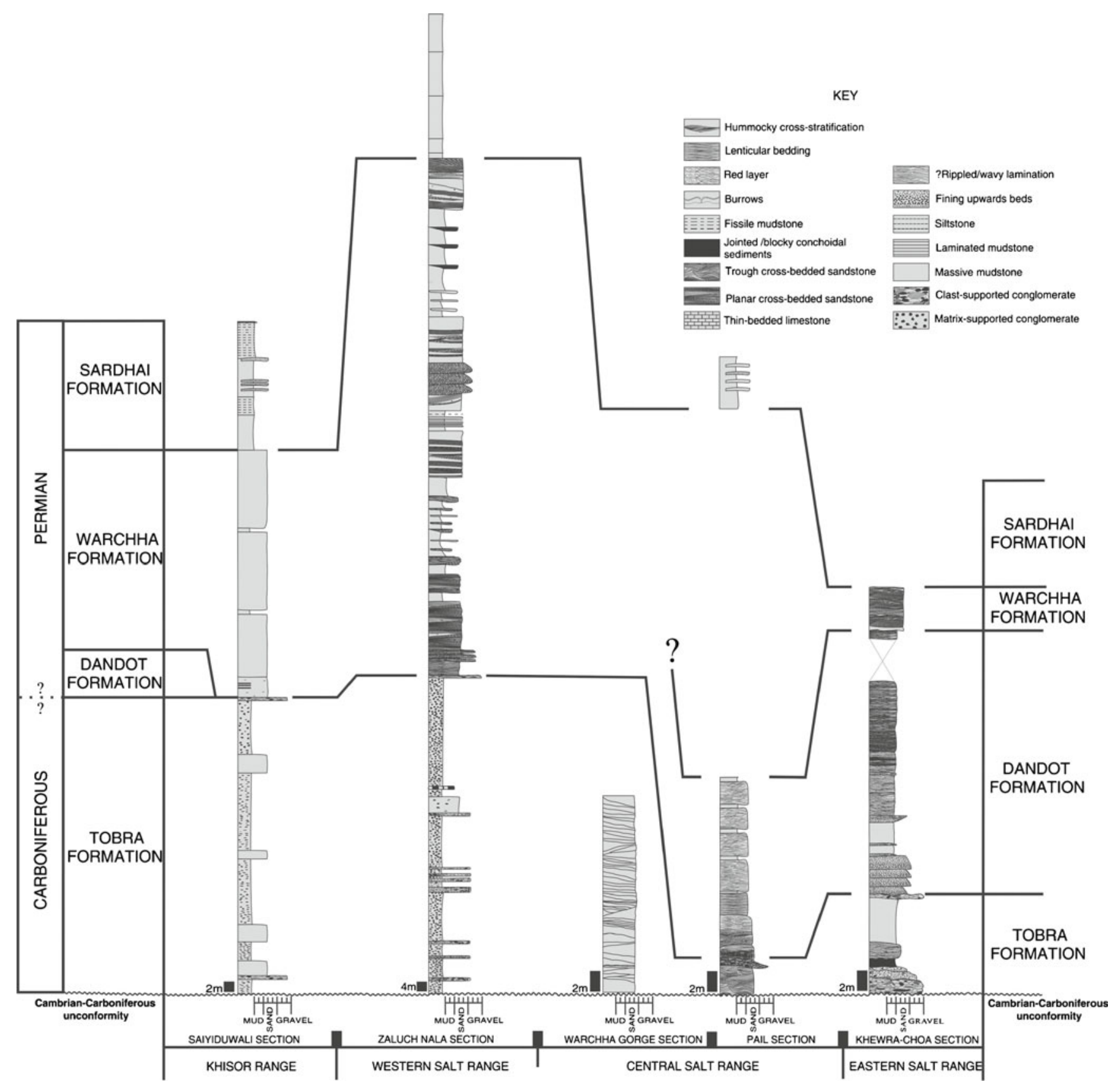

Figure 3. Carboniferous-Permian stratigraphy of the Salt and Khisor ranges, Pakistan. The Dandot Formation is missing in the western Salt Range and in the Khisor Range (modified after Jan and Stephenson 2011).

assemblages have shown a slight variation from west to east and are briefly discussed below.

\subsubsection{The palynomorph assemblages of the Tobra Formation}

\subsubsection{Palynomorphs of the Tobra Formation at the Zaluch Nala section, western Salt}

$$
\text { Range, Pakistan }
$$

The palynomorphs in the Tobra Formation at the Zaluch Nala section are represented by 41 species belonging to 20 genera (figure 4). Spores are more diverse than any other group, represented by 10 genera and 22 species. Horriditriletes show five species, followed by Brevitriletes, representing four species and Punctatisporites is represented by three species. Cristatisporites and Vallatisporites are represented by two species each. All other spore genera are represented by only one species. The monosaccate pollen are represented by five genera and nine species; Plicatipollenites, and Potonieisporites are represented by three species and Cannanoropollis is represented by two species. The bisaccate pollen are represented by the least number in the Tobra Formation, i.e., four genera and eight species. Protohaploxypinus 
Table 1. List of taxa recorded.

Alisporites sp.

Alisporites indarraensis Segroves (1969)

Alisporites cf. nuthallensis Clarke (1965)

Brevitriletes sp.

Brevitriletes leptoacaina Jones and Truswell (1992)

Brevitriletes parmatus (Balme and Hennelly) Backhouse (1991)

Brevitriletes cornutus (Balme and Hennelly) Backhouse (1991)

Barakarites cf. rotatus (Balme and Hennelly) Bharadwaj and Tiwari (1964)

Barakarites rotatus (Balme and Hennelly) Bharadwaj and Tiwari (1964)

Camptotriletes warchianus Balme (1970)

Corisaccites alutas Venkatachala and Kar (1966)

Cedripites sp.

Cannanoropollis janakii Potonié and Sah (1960)

Complexisporites polymorphus Jizba (1962)

Cristatisporites crassilabratus Archangelsky and Gamerro (1979)

Converrucosisporites grandegranulatus (Anderson) Lindström (1995)

Cycadopites cymbatus (Balme and Hennelly) Segroves (1970)

Distriatites sp.

Florinites? balmei Stephenson and Filatoff (2000)

Guttulapollenites hannonicus Goubin (1965)

Horriditriletes tereteangulatus (Balme and Hennelly) Backhouse (1991)

Horriditriletes ramosus (Balme and Hennelly) Bharadwaj and Salujah (1964)

Horriditriletes uruguaiensis (Marques-Toigo) Archangelsky and Gamerro (1979)

Hamiapollenites sp.

Hamiapollenites dettmannae Segroves (1969)

Hamiapollenites karrooensis (Hart) Hart (1964)

Kingiacolpites subcircularis Tiwari and Moiz (1971)

Laevigatosporites callosus Balme (1970)

Lueckisporites virkkiae Potonié and Klaus emended Clarke (1965)

Lundbladispora sp.

Lundbladispora braziliensis (Pant and Srivastava) emend. Marques-Toigo and Picarelli (1984)

Limitisporites rectus Leschik (1956)

Microbaculispora tentula Tiwari (1965)

Punctatisporites spp.

Protohaploxypinus uttingii Stephenson and Filatoff (2000)

Protohaploxypinus sp.

Plicatipollenites sp.

Potonieisporites sp.

Plicatipollenites malabarensis (Potonié and Sah) Foster (1979)

Potonieisporites novicus Bharadwaj (1954)

Punctatisporites ubischii Foster (1979)

Potonieisporites brasiliensis (Nahuys, Alpern and Ybert) Archangelsky and Gamerro (1979)

Plicatipollenites densus Srivastava (1970)

Protohaploxypinus cf. hartii Foster (1979)

Retusotriletes sp.

Striatopodocarpites cancellatus (Balme and Hennelly) Bharadwaj (1962)

Striatopodocarpites fusus (Balme and Hennelly) Potonié (1958)

Strotersporites indicus Tiwari (1965)

Spelaeotriletes sp.

Thymospora opaqua Singh (1964)

Taeniaesporites sp.

Vallatisporites arcuatus (Marques-Toigo) Archangelsky and Gamerro (1979)

Verrucosisporites andersonii (Anderson) Backhouse (1988) 


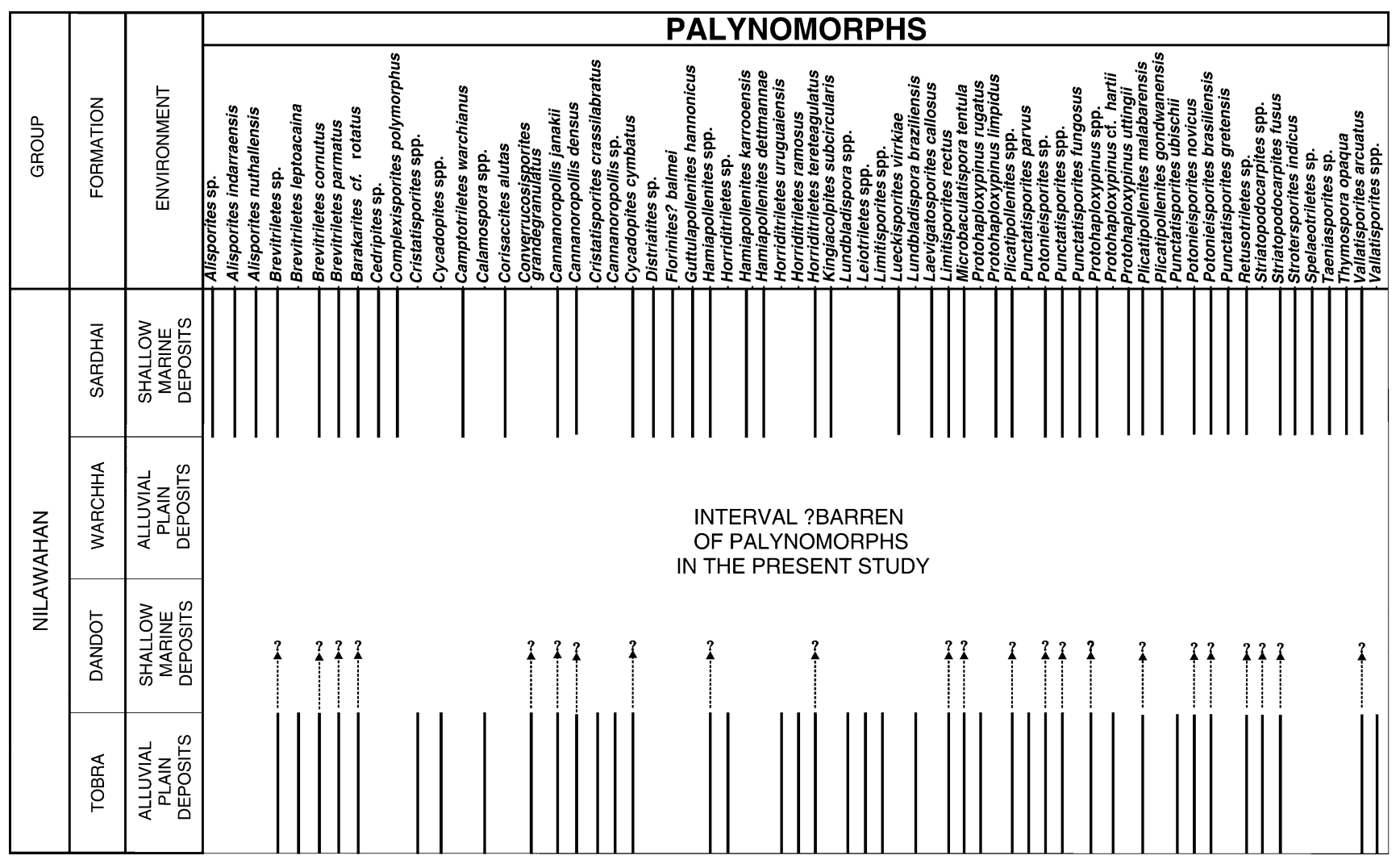

Figure 4. Palynomorph range chart of the Nilawahan Group. Taxa are found in the Tobra and Sardhai formations. The Dandot and Warchha formations are barren.

is represented by three species whereas Striatopodocarpites and Limitisporites are represented by two species each. All other bisaccate genera are represented by only one species. The monocolpate pollen are represented by two species. The stratigraphically diagnostic taxa in the Tobra Formation at the Zaluch Nala section include, Brevitriletes cornutus, Brevitriletes parmatus, Brevitriletes leptoacaina, Converrucosisporites grandegranulatus, Cycadopites cymbatus, Horriditriletes tereteangulatus, Horriditriletes ramosus and Microbaculispora tentula (figure 4).

\subsubsection{Palynomorph assemblages of the Tobra Formation at the Khewra-Choa section, eastern Salt Range, Pakistan}

The palynomorphs in the Tobra Formation at the Khewra-Choa section are represented by the same taxa as those from the Zaluch Nala section, however a slight change in the qualitative character has been observed. The single most stratigraphically important taxon that differentiates the palynomorph assemblages of the Tobra Formation at the Khewra-Choa section from that of Tobra Formation at the Zaluch Nala section is the presence of Converrucosisporites confluens (e.g., Stephenson et al. 2013). Other stratigraphically important taxa in the Tobra Formation at the Khewra-Choa section include, Brevitriletes cornutus and Microbaculispora tentula.

\subsubsection{The palynomorph assemblages of the Sardhai Formation}

In the Sardhai Formation, an increase in the diversity of genera, compared to the Tobra Formation is observed (figure 4). Whilst some species and genera are found to extend from the Tobra Formation, others are observed to terminate in the Sardhai Formation; some new taxa also appear in the Sardhai Formation. Spores still constitute a major proportion of the palynomorph types and are represented by 15 species belonging to 11 genera. The spore species that first occur at the base of the Sardhai Formation belong to genera Camptotriletes, Laevigatosporites and Thymospora, whereas Cristatisporites, Horriditriletes and Calamospora disappear in the Sardhai Formation. The bisaccate pollen represent the second most common category. They are represented by eight genera and 15 species. The bisaccate pollen that originate at this level include Alisporites, Corisaccites, Complexisporites and Lueckisporites. The bisaccate pollen genus that is observed to terminate in the Sardhai Formation is Limitisporites. 
Monosaccate pollen are represented by seven genera and 11 species in the Sardhai Formation. The newly introduced species include Florinites and Guttulapollenites. The stratigraphically diagnostic taxa include, Corisaccites alutas, Protohaploxypinus uttingii, Florinites? balmei, Thymospora opaqua, Camptotriletes warchianus and Lueckisporites virkkiae.

\section{Carboniferous-Permian stratigraphic correlation of the Nilawahan Group of Pakistan}

Earlier, attempts were made to correlate various microfossil groups of Permian Zaluch Group of the Salt Range with the Gondwanan continents (e.g., Kummel and Teichert 1970 and references therein; Balme 1970). However, studies pertaining to the biostratigraphic correlation of the stratigraphically older group, i.e., Nilawahan Group of the area (figure 3), with the presently far-off continents of Gondwana were scarce. Recently, Jan et al. (2009), Jan (2011), Jan and Stephenson (2011) and Stephenson et al. (2013) attempted to fit parts of these successions (i.e., the stratigraphically lowermost Tobra and uppermost Sardhai formations) in the Gondwanan stratigraphic framework.

\subsection{Palynostratigraphic correlation of the Tobra Formation with the Arabian sections (Oman, Saudi Arabia and Yemen)}

Jan and Stephenson (2011) studied the Tobra Formation at the western Salt Range Zaluch Nala section and presence of stratigraphically diagnostic taxa in this unit, e.g., Horriditriletes tereteangulatus, Horriditriletes ramosus, Horriditriletes uruguaiensis and Microbaculispora tentula have helped the workers to suggest the palynostratigraphic correlation of the unit with the South Oman 2165B biozone (Penney et al. 2008) and the lower part of the Oman and Saudi Arabia Palynological Zone 2 (OSPZ2) biozone (Stephenson et al. 2003). The age assigned to the Tobra Formation is Upper Pennsylvanian, since the Tobra Formation palynological assemblages at the Zaluch Nala section unlike South Oman and Saudi Arabian assemblages (figure 5) lack the Converrucosisporites confluens. Whereas the Microbaculispora tentula still constitutes the major portion of these assemblages. The South Oman 2165B biozone falls in the upper part of the glacigenic Al Khlata Formation and the Saudi Arabia OSPZ2 biozone is present in the Unayzah B member (figure 5).

Stephenson et al. (2013) studied palynological assemblages from the Tobra Formation at the Khewra-Choa section, eastern Salt Range (figure 3), and reported the presence of Converrucosisporites confluens. The Tobra Formation is thus assigned an Early Permian, Asselian age (Stephenson et al. 2013).

Palynology of the Khulan Formation of Yemen has been recently studied by Stephenson and AlMashaikie (2010, 2011) and Stephenson et al. (2013). The Tobra Formation assemblages are tentatively correlated with the lower part of the Khulan Formation, Yemen, with the portion where certain taxa, e.g., Brevitriletes cornutus, B. parmatus and Microbaculispora tentula occur. However, the Tobra Formation assemblages deviate from the Khulan Formation palynological assemblages by lacking taxa like, Anapiculatisporites concinnus, Deusilites tentus, Dibolisporites disfacies and Spelaeotriletes triangulus (Jan 2011; figure 5).

\subsection{Palynostratigraphic correlation of the Tobra Formation with Australian basins}

Jan and Stephenson (2011) correlated the palynological assemblages of the Tobra Formation with those from Stage 2 (sensu Backhouse 1991) and the eastern Australian Microbaculispora tentula Oppel-zone (Jones and Truswell 1992). The Tobra Formation can be correlated with the Stockton Formation of the Collie Basin, western Australia and the upper Jochmus Formation, eastern Australian Galilee Basin (figure 5).

\subsection{Palynostratigraphic correlation of the Tobra Formation with the Chacoparana Basin and central-western Argentina}

A tentative correlation of the Tobra Formation is extended with those of the South American sections (Jan 2011). The palynozonation scheme of the Chacoparana Basin, Argentina was established by Russo et al. (1980). These workers formulated three palynozones in the Upper Palaeozoic Ordóñez and Victoria Rodríguez formations, namely, Potonieisporites-Lundbladispora, Cristatisporites and Striatites Zones. The refinement of this scheme by Vergel (1993) and later by Playford and Dino (2002) showed that the base of the upper part of Potonieisporites-Lundbladispora Zone is represented by the first occurrence of Cristatisporites crassilabratus and Horriditriletes uruguaiensis. The biozone also contains Caheniasaccites ovatus, Cannanoropollis janakii, Granulatisporites austroamericanus (= Microbaculispora tentula), Potonieisporites brasiliensis, Potonieisporites novicus, Plicatipollenites malabarensis, Cannanoropollis densus and Plicatipollenites malabarensis. However, these taxa are extended 


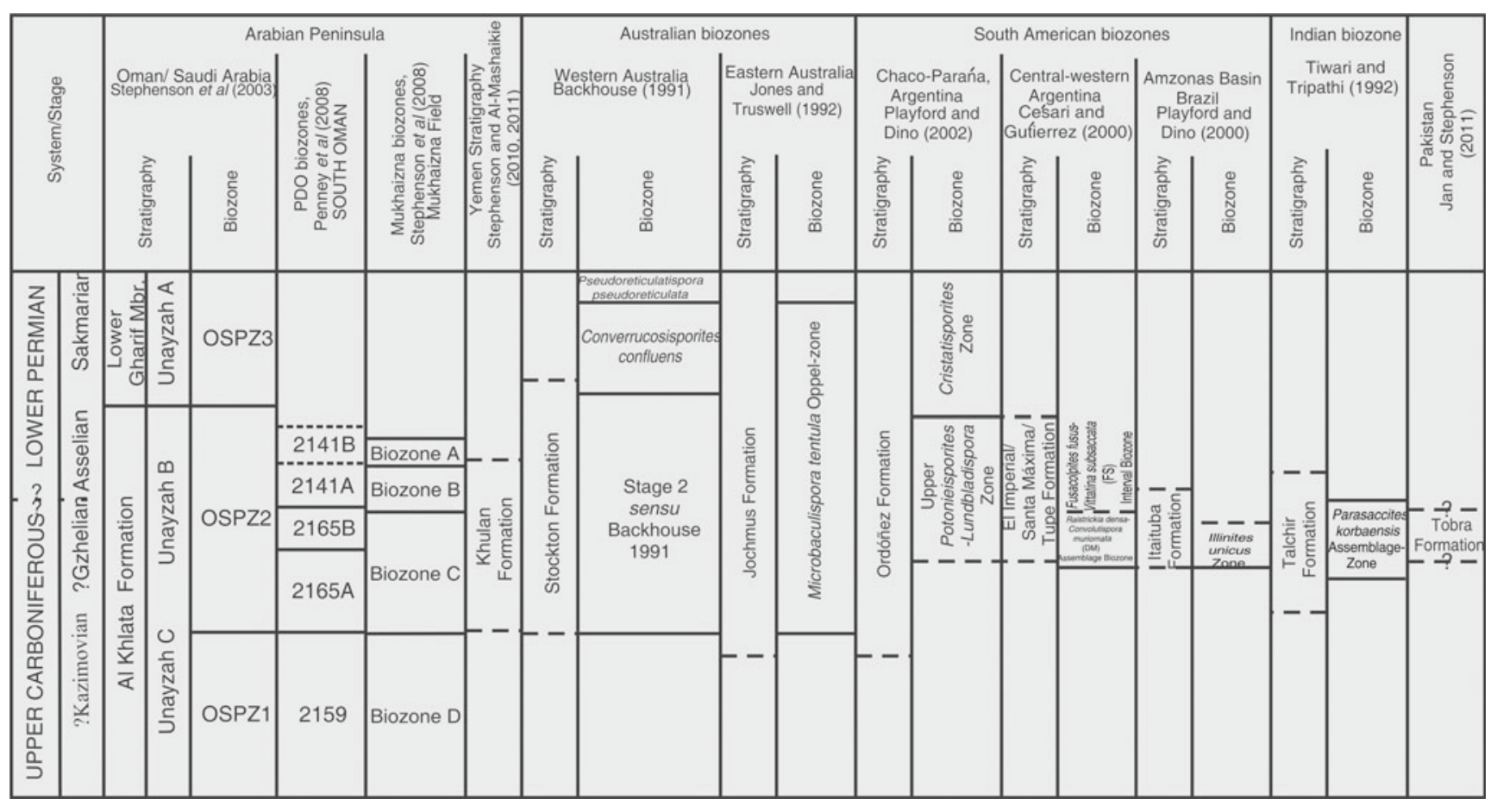

Figure 5. Stratigraphic and biozonal correlation of the Tobra Formation, Pakistan with Arabian, Australian, South American and Indian sections (modified after Jan and Stephenson 2011).

from the lower part of the PotonieisporitesLundbladispora Zone. The overlying Cristatisporites Zone has abundant zonate-cavate spores, e.g., Converrucosisporites micronodosus, Converrucosisporites confluens, Lundbladispora braziliensis and Vittatina saccata. The Tobra Formation assemblages can be correlated with the upper part of the Potonieisporites-Lundbladispora Zone, based on the presence of Cristatisporites crassilabratus and Horriditriletes uruguaiensis and thus the Tobra Formation is correlative with the upper part of the Ordóñez Formation (Russo et al. 1980; Vergel 1993; figure 5).

In the central-western Argentina, the Raistrickia densa-Convolutispora muriornata (DM) Assemblage Biozone (Césari and Guitiérez 2000), is characterised by monosaccate pollen particularly Plicatipollenites spp., Potonieisporites spp., and Cannanoropollis spp. This biozone is also represented by the bisaccate pollen Protohaploxypinus spp. The Tobra Formation, Zaluch Nala palynological assemblages can be correlated with the Raistrickia densa-Convolutispora muriornata (DM) Assemblage Biozone, as they contain Cannanoropollis spp., Plicatipollenites spp., and Protohaploxypinus spp.

The difference between the Tobra Formation, Zaluch Nala palynological assemblages and the Raistrickia densa-Convolutispora muriornata (DM) Assemblage Biozone of central-western
Argentina is in the absence of certain taxa, e.g., Apiculiretusispora variornata, A. alonsoi, A. teuberculata, Anapiculatisporites argentinensis, Convolutispora muriornata, Cristatisporites inconstans, Foveosporites hortonensis, Granulatisporites varigranifer, Raistrickia rotunda, $R$. densa and Vallatisporites ciliaris in the Tupe Formation. The base of the overlying Fusacolpites fususVittatina subsaccata (FS) Interval Biozone (Césari and Guitiérez 2000), is marked by first appearance of Fusacolpites fusus and increase in the striate pollen grain. The taxa typical to this biozone include Barakarites rotatus, Vittatina subsaccata, Hamiapollenites fusiformis, Striatoabieites multistriatus, Granulatisporites sp., Lophotriletes rarus and Apiculatisporis cornutus. The presence of Barakarites cf. rotatus in the Tobra Formation, Zaluch Nala assemblages also favours tentative correlation of the assemblages with the Fusacolpites fusus-Vittatina subsaccata (FS) Interval Biozone. However, no common taxa are found between the Tobra Formation palynological assemblages and those of the stratigraphically older Cordylosporites-Verrucosisporites (CV) Assemblage Biozone. This shows that the Tobra Formation is equivalent to the El Imperial Formation of the San Rafael, the Santa Máxima Formation of the Calingasta-Uspallata Basin and the Tupe Formation of the Paganzo Basin of the central-western Argentina (figure 5). 


\begin{tabular}{|c|c|c|c|c|c|c|c|c|}
\hline \multirow{2}{*}{\multicolumn{2}{|c|}{ Chronostratigraphy }} & \multirow[b]{2}{*}{$\begin{array}{c}\text { Palynological } \\
\text { Biozonation (South Oman) } \\
\text { Stephenson et al } 2013\end{array}$} & \multicolumn{5}{|c|}{ Lithostratigraphy } & \multirow{3}{*}{ F.? balmei FAD } \\
\hline & & & \begin{tabular}{|c} 
Southeast Turkey \\
Stolle 2007
\end{tabular} & $\begin{array}{l}\text { North Iraq } \\
\text { Stolle } 2007\end{array}$ & $\begin{array}{c}\text { Central } \\
\text { Saudi Arabia } \\
\text { Stephenson et al } 2013\end{array}$ & $\begin{array}{c}\text { Oman } \\
\text { Stephenson et al } 2013\end{array}$ & $\begin{array}{c}\text { Pakistan } \\
\text { Jan et al } 2009\end{array}$ & \\
\hline \multirow{3}{*}{ 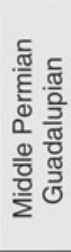 } & Capitanian & \multirow[t]{2}{*}{ OSPZ6 } & $\begin{array}{c}\text { Gomaniibrik } \\
\text { Formation } \\
\text { (part) }\end{array}$ & \multirow{2}{*}{$\begin{array}{l}\text { Chia Zairi } \\
\text { Formation } \\
\text { (part) } \\
\text { Zinner } \\
\text { - Clastics }\end{array}$} & $\begin{array}{l}\text { Khuff } \\
\text { Formation } \\
\text { (part) }\end{array}$ & $\begin{array}{l}\text { Upper part of } \\
\text { Khuff Formation } \\
\text { missing }\end{array}$ & \multirow[t]{2}{*}{$\begin{array}{l}\text { Zaluch } \\
\text { Carbonates } \\
\text { (part) }\end{array}$} & \\
\hline & \multirow{2}{*}{ Wordian } & & Kas Formation & & \multirow{2}{*}{$\begin{array}{l}\text { Basal Khuff clastics } \\
\text { sensu Stephenson } \\
\text { and Filatoff (2000) }\end{array}$} & - Khưuff Formation- - & & \\
\hline & & OSPZ5 & BPBP & $\begin{array}{l}\text { Ga'ara Formation } \\
\text { (subsurface) }\end{array}$ & & 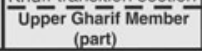 & & \\
\hline
\end{tabular}

Figure 6. Extension of the Oman and Saudi Arabia palynological zones 6 (i.e., OSPZ6) in to the Tethyan region and correlation of the Sardhai Formation, Salt Range, Pakistan. FAD in the last column stands for first occurrence datum of F.? balmei (modified after Jan et al. 2009).

\subsection{Palynostratigraphic correlation of the Tobra Formation with the Amazonas Basin, Brazil}

The Amazonas Basin, Brazil's Illinites unicus Zone is defined by the association of Illinites unicus, Spelaeotriletes triangulus, S. arenaceus and spores like Vallatisporites and Cristatisporites. Protohaploxypinus spp., show an increase from the lower palynozone, i.e., Striomonosaccites incrassatus Zone (Playford and Dino 2000). The lower limit of the Illinites unicus Zone is well delineated by incoming taxa such as, Barakarites rotatus, Cycadopites sp., and Vallatisporites arcuatus, whereas the top of this biozone (and the base of the overlying Stratosporites heyleri Zone), is marked by the introduction of Apiculatasporites daemonii. The Tobra Formation palynological assemblages representing Barakarites cf. rotatus, Vallatisporites arcuatus and Cycadopites sp., and lacking Apiculatasporites daemonii, can be correlated tentatively with the Illinites unicus Zone and thus with the Itaituba Formation (Playford and Dino 2000; figure 5).

\subsection{Palynostratigraphic correlation of the Tobra Formation with Indian section}

The base of the Indian Parasaccites korbaensis Assemblage Zone (Tiwari and Tripathi 1992) is defined by the first occurrence of Microbaculispora tentula and Microfoveolatispora foveolata. Other taxa common in this biozone are Parasaccites korbaensis, Callumispora gretensis, Circumstriatites obscurus and C. talchirensis. The top of this biozone is defined by the oldest occurrence of Crucisaccites monoletus. A tentative correlation of the Tobra Formation palynological assemblages is suggested with the Parasaccites korbaensis Assemblage Zone. Based on the presence of Microbaculispora tentula in the Tobra Formation assemblages, it can be assumed that the assemblages are at least not older than the Parasaccites korbaensis Assemblage Zone, which is represented by the first occurrence datum (FAD) of Microbaculispora tentula and occurs in the upper part of the Talchir Formation (Tiwari and Tripathi 1992; figure 5).

\section{Palynostratigraphic correlation of the Sardhai Formation with Tethyan sections}

Jan et al. (2009) reported the Florinites? balmei in the Sardhai Formation, with stratigraphically important taxa, e.g., Camptotriletes warchianus and suggested correlation with the southern Tethyan units. The Sardhai Formation was thus correlated with the Khuff transition beds of Oman, and the basal Khuff clastics of central Saudi Arabia and was assigned to the Arabian OSPZ6 biozone, indicating Wordian age (figure 6). The Sardhai Formation assemblages are also correlated with the Kas Formation of Southeast Turkey (Stolle 2007).

The work of Jan et al. (2009) showed that monosaccate pollen grain Florinites? balmei had a limited palaeogeographic distribution in the MidPermian across most of the southern Tethys and Arabia. The taxon is considered endemic to the area of the southern neo-Tethys.

\section{Discussion}

The recent progress in the stratigraphic palynology in the Carboniferous-Permian sections of the Gondwana has greatly helped correlation of these successions within the basins and with the Russian/International stages. Due to the lack of age-defining fauna in these Gondwanan succession, palynology has become an important means of biostratigraphic correlation. However, reliability and confidence of the palynozones remains in their calibration either with the bounding marine intervals (e.g., in Australia and Arabia) or with the radiometric dating of the contained strata (e.g., 
Africa and South America). The present advancement in identifying and understanding of the intermittent marine intervals, having age-diagnostic cosmopolitan fauna has helped in calibrating the palynozones with the Russian/International stages. This and the progress in the radiometric dates of tuffs (e.g., $302.0 \pm 3.0$ Ma, i.e., Pennsylvanian; Gzhelian or Kasimovian; South Africa; Bangert 2000) present in certain horizons of these Gondwanan deposits have given great confidence for the age calibration of these palynozones.

The palynological assemblages of the Tobra and Sardhai formations of the Salt Range Pakistan have thus been calibrated and the successions have been put in the regional stratigraphic framework. Recent palynostratigraphic investigations (published, i.e., Jan et al. 2009; Jan and Stephenson 2011; Stephenson et al. 2013 and unpublished, i.e., Jan 2011) of these successions have helped in their correlation with successions in the Arabia (Middle East), Australia, South America and India as follows.

The Tobra Formation (figure 5) correlates with:

- The middle to upper part of the Al Khlata Formation of Oman and the Unayzah B member of the Saudi Arabia (Jan and Stephenson 2011).

- The lower part of the Khulan Formation of Yemen (Stephenson and Al-Mashaikie 2010, 2011).

- The Stockton Formation of the Collie Basin of western Australia.

- The Upper Jochmus Formation of the eastern Australian Galilee Basin.

- The upper part of the Ordóñez Formation (Russo et al. 1980; Vergel 1993; Playford and Dino 2002), the El Imperial Formation of the San Rafael, the Santa Máxima Formation of the CalingastaUspallata Basin, the Tupe Formation of the Paganzo Basin of the central-western Argentina and the Itaituba Formation of the Brazil (Playford and Dino 2000).

- The upper part of the Talchir Formation (Tiwari and Tripathi 1992).

The Sardhai Formation (figure 6) correlate with:

- The Khuff transition beds of Oman (Stephenson et al. 2003).

- The basal Khuff clastics of central Saudi Arabia (Stephenson et al. 2003).

- The Kas Formation of south-eastern Turkey (Stolle 2007).

Hydrocarbons in the Arabian Peninsula are significantly produced from the CarboniferousPermian Al Khlata, Gharif and Unayzah formations. The lithological (Jan et al., in review) and palynological/palaeontological similarities (Jan et al. 2009; Jan 2011; Jan and Stephenson 2011; Stephenson et al. 2013) between CarboniferousPermian succession of Pakistan and those of the Middle East suggest that the Salt Range provides good analogues for the subsurface Al Khlata, Gharif and Unayzah formations of the Arabian Peninsula. The Carboniferous-Permian facies associations observed in outcrop in Pakistan (Jan et al., in review) are providing a useful insight into the stratigraphic architecture of the key hydrocarbon reservoirs in the subsurface of the Arabian Peninsula.

The correlation of the Pakistan units with the Gondwana sections helps to understand the chronological position of the Salt Range units in the context of the late Palaeozoic ice age (i.e., representing deposition in the last stages of the Carboniferous-Permian glaciations) and hence these events can be studied in the Pakistan succession in the future once their complete stratigraphic frameworking is accomplished with regard to the Gondwanan succession. This correlation gives a great chance for these successions to be studied for their hydrocarbon and coal potentials.

\section{Acknowledgements}

This study presents a brief review of the latest palynostratigraphic work conducted on the Carboniferous-Permian succession of Pakistan. The earlier published and the currently in progress work benefited from the Higher Education Commission of Pakistan's NRPU (National Research Program for Universities grant to Dr Irfan U Jan). The anonymous reviewers are thanked for their constructive criticism on the manuscript.

\section{References}

Amos A J and López-Gamundi O R 1981 Late Paleozoic Sauce Grande Formation of eastern Argentina; In: Earth's Pre-Pleistocene Glacial Record (eds) Hambrey M J and Harland W B, Cambridge University Press, pp. 872-877.

Archbold N W 1999 Permian Gondwanan correlations: The significance of the western Australian marine Permian; J. African Earth Sci. 29 63-75.

Archbold N W and Dickins J M 1997 Comments on subdivisions of the Permian and a standard world scale; Permophiles 30 4-5.

Backhouse J 1991 Permian palynostratigraphy of the Collie Basin, western Australia; Rev. Palaeobot. Palynol. 67 237-314.

Balme B E 1970 Palynology of Permian and Triassic strata in the Salt Range and Surghar Range, west Pakistan; In: Stratigraphic Boundary Problems: Permian and Triassic of West Pakistan (eds) Kummel B and Teichert C, Univ. Kansas Spec. Publ., pp. 306-453.

Bangert B 2000 Tephrostratigraphy, petrography, geochemistry, age and fossil record of the Ganigobis Shale Member and associated glaciomarine deposits of the Dwyka 
Group, Late Carboniferous, southern Africa, PhD thesis, Bayerischen Julius-Maximilians-Universität, Würzburg, Germany.

Bangert B, Stollhofen H, Lorenz V and Armstrong R 1999 The geochronology of ash-fall tuffs in the glaciogenic Carboniferous-Permian Dwyka Group of Namibia and South Africa; J. African Earth Sci. 29 33-49.

Césari S N 2007 Palynological biozones and radiometric data at the Carboniferous-Permian boundary at western Gondwana; Gondwana Res. 11 529-536.

Césari S N and Guitiérez P R 2000 Palynostratigraphy of Upper Paleozoic sequences in central-western Argentina; Palynology 24 113-146.

Foster C B and Waterhouse J B 1988 The Granulatisporites confluens Oppel-zone and Early Permian marine faunas from the Grant Formation on the Barbwire Terrace, Canning Basin, Australia; Austr. J. Earth Sci. 35 135-157.

Frakes L A, Kemp E M and Crowel J C 1975 Late Paleozoic Glaciation. Part VI: Asia; Bull. Geol. Soc. Am. 86 454-464.

Gee E R 1989 Overview of the geology and structure of the Salt Range, with observation on related areas of northern Pakistan; In: Tectonics of the Western Himalayas (eds) Malinconico L L and Lillie R J, Geol. Soc. Am. Spec. Paper 232 95-112.

Ghazi S and Mountney N P 2009 Facies and architectural element analysis of a meandering fluvial succession: The Permian Warchha Sandstone, Salt Range, Pakistan; Sedim. Geol. 221 99-126.

Ghazi S, Mountney N P, Butt A A and Sadaf S 2012 Stratigraphic and palaeoenvironmental framework of the Early Permian sequence in the Salt Range, Pakistan; J. Earth Syst. Sci. 121 1239-1255.

Isbell J L, Gelhar G A and Seeger G M 1997 Reconstruction of pre-glacial topography using a post-glacial flooding surface; upper Paleozoic deposits, central Transantarctic Mountains, Antarctica; J. Sedim. Res. 67 264-272.

Jan I U 2011 Investigating the palynostratigraphy and palaeoenvironments of the southern Palaeotethyan Carboniferous-Permian succession of the Salt Range, Pakistan, PhD thesis, University of Leicester, UK.

Jan I U 2012 In front of Himalayas: New discoveries in the Salt Range, Pakistan; Comm. Intern. de Micro. du Palé. News Letter 79 22-23.

Jan I U and Stephenson M H 2011 Palynology and correlation of the Upper Pennsylvanian Tobra Formation from Zaluch Nala, Salt Range, Pakistan; Palynology 35212 225.

Jan I U, Stephenson M H and Khan F R 2009 Palynostratigraphic correlation of the Sardhai Formation (Permian) of Pakistan; Rev. Palaeobot. Palynol. 158 72-82.

Jan I U, Davies S J, Zalasiewicz J A, Stephenson M H, Haneef M, Hanif M, Iqbal S and Shah A, Palaeoenvironmental analysis of the Carboniferous-Permian Tobra Formation of the low latitude Tethyan Salt Range, Pakistan; J. Earth Syst. Sci. (under review).

Jin Y, Wardlaw B R, Glenister B F and Kotlyar G V 1997 Permian chronostratigraphic subdivisions; Episodes 20 $10-15$.

Jones M J and Truswell E M 1992 Late Carboniferous and Early Permian palynostratigraphy of the Joe Joe Group, southern Galilee Basin, Queensland and implications for Gondwana stratigraphy. Bureau of Mines and Mineral Resources; J. Austral. Geol. Geophys. 13 143-185.

Kummel B and Teichert C 1970 Stratigraphy and paleontology of the Permian-Triassic Boundary Beds, Salt Range and Trans-Indus Ranges, West Pakistan; In: Stratigraphic Boundary Problems: Permian and Triassic of West Pakistan (eds) Kummel B and Teichert C, Univ. Kansas Spec. Publ. 4 2-110.
Kyles R A and Schopf J M 1982 Permian and Triassic palynostratigraphy of the Victoria Group, Transantarctic Mountains; In: Antarctic Geosciences (ed.) Craddock C (Madison: Univ. Wiscon. Press), pp. 649-659.

Lindström S 1995 Early Permian palynostratigraphy of the Northern Heimefrontfjella Mountain-Range, Dronning Maud Land, Antarctica; Rev. Palaeobot. Palynol. 89 359-415.

López-Gamundi O R 1989 Postglacial transgressions in late Palaozoic Basins of western Argentina: A record of glacioeustatic sea level rise; Palaeogeogr. Palaeoclimatol. Palaeoecol. 71 257-270.

Pascoe E S 1959 A Manual of the Geology of India and Burma (Calcutta: Government of India Press) 2 3851343.

Penney R A, Al Barram I and Stephenson M H 2008 A high resolution palynozonation for the Al Khlata Formation (Pennsylvanian to Lower Permian), South Oman; Palynology 32 213-229.

Playford G and Dino R 2000 Palynostratigraphy of the upper Palaeozoic strata (Tapajos Group). Amazonas Basin, Brazil: Part One; Palaeontog. Abt. B 255 1-46.

Playford G and Dino R 2002 Permian palynofloral assemblages of the Chaco-Paraná Basin, Argentina: Systematics and stratigraphic significance; Revi. Esp. de Microp. $34235-288$.

Reed F R C 1936 Some fossils from the Eurydesma and Conularia beds (Punjabian) of the Salt Range; Geol. Surv. India Memoir, Pal. Indica (NS) 23 1-36.

Roberts J, Claoué- Long J and Foster C B 1996 SHRIMP zircon dating of the Permian System of eastern Australia; Austr. J. Earth Sci. 43 401-421.

Russo A S, Archangelsky S and Gamerro J C 1980 Los depósitas supra Palaeozoicos en el subsuelo de la Llanura Chaco-Pampeana, Argentina; Actas del II Congreso Argentino de Paleontología y Bioestratigrafía y I Congreso Latinoamericano de Paleontología 19784 157-173.

Shah S M I 1977 Stratigraphy of Pakistan; Geol. Surv. Pakistan Memoir 12138.

Stephenson M H 2008 A review of the palynostratigraphy of Gondwanan Late Carboniferous to Early Permian glacigene succession; In: Resolving the Late Paleozoic Ice Age in Time and Space (eds) Fielding C R, Frank T D and Isbell J L, Geol. Soc. Am. Spec. Publ. 441 $317-330$.

Stephenson M H and Al-Mashaikie S Z A K 2010 New age for the lower part of the Kuhlan Formation, northwest Yemen; GeoArabia 15 161-170.

Stephenson M H and Al-Mashaikie S Z A K 2011 Stratigraphic note: Update on the palynology of the Akbarah and Kuhlan formations, northwest Yemen; GeoArabia 16 $17-24$.

Stephenson M H, Osterloff P L and Filatoff J 2003 Palynological biozonation of the Permian of Oman and Saudi Arabia: Progress and challenges; GeoArabia 8 467-496.

Stephenson M H, Jan I U and Al-Mashaikie S Z A K 2013 Palynology and correlation of Pennsylvanian glacigene rocks in Oman, Yemen and Pakistan; Gondwana Res. 24 203-211.

Stolle E 2007 Regional Permian palynological correlations: Southeast Turkey-Northern Iraq; Comuni. Geol. 94 125-143.

Sultan S A 2004 Mineralogical investigations of the phosphatic nodules from Warchha sandstone, Salt Range with emphasis on replacement process; Geol. Bull. Univ. Pesh. 37 65-75.

Tiwari R S and Tripathi A 1992 Palynological zones and their climatic inference in the coal-bearing Gondwana of peninsular India; Palaeobotanist 36 87-101. 
Vergel M D M 1993 Palinoestratigrafía de la secuencia Neopaleozoica en la Cuenca Chacoparanense Argentina; Douzième Congrès International de la Stratigraphie et de Géologie du Carbonifère et Permien, Compte Rendus $\mathbf{1}$ 201-212.

Visser J N J 1997 Deglaciation sequences in the PermoCarboniferous Karoo and Kalahari basins of southern
Africa: A tool in the analysis of cyclic glaciomarine basin fills; Sedimentology 44 507-521.

Wardlaw B R and Pogue K R 1995 The Permian of Pakistan; In: The Permian of Northern Pangea volume 1. Palaeogeography, Palaeoclimates, Stratigraphy (eds) Scholle P A, Peryt T M and Ulmer-Scholle P M (New York: Springer Verlag), pp. 215-224. 